\title{
Mortality among women and men relative to unemployment, part time work, overtime work, and extra work: a study based on data from the Swedish twin registry
}

\author{
L Nylén, M Voss, B Floderus
}

\begin{abstract}
Objective-To examine mortality before 70 years of age among women and men relative to unemployment, part time work, overtime work, and extra work. Age, marital status, children, smoking and alcohol habits, use of sleeping pills and tranquilisers, stress, shift work, personality factors, and long lasting or serious illness were taken into account as potential confounding factors.

Methods-The study group comprised a subcohort of the Swedish twin registry, people born in 1926-58. Data were based on a postal questionnaire of 1973 and on information from the Swedish Causes of Death Registry. All subjects reporting a main occupation were selected, 9500 women and 11132 men, and mortality from all causes during 1973-96 was analysed. The subjects were treated as a sample from the general population regardless of the twinning.
\end{abstract} both women and men showed an association with increased mortality. The adjusted relative risk (RR) $(95 \%$ confidence interval (95\% CI)) was 1.98 (1.16 to 3.38 ), for women and 1.43 (0.91 to 2.25$)$ for men. For the first 5 years of follow up, a threefold increase in risk was found for men (RR (95\% CI) 3.29 (1.33 to 8.17)). The RR declined by time, but remained increased throughout the 24 year study period. In women overtime work of more than 5 hours a week was followed by an increased mortality rate (RR $(95 \% \mathrm{CI})$ $1.92(1.13$ to 3.25$))$. A protective effect of moderate overtime work of a maximum 5 hours a week was shown for men (RR $(95 \%$ CI) $0.58(0.43$ to 0.80$))$, whereas an increased mortality was indicated for part time work (RR (95\% CI) 1.58 (0.91 to 2.77)) and extra work (work outside employment) of more than 5 hours a week (RR (95\% CI) 1.29 (0.99 to 1.69$)$ ).

Conclusion-Unemployment and some time aspects of work were associated with subsequent mortality, even when controlling for social, behavioural, work, and health related factors. The idea that losing a job may have less importance for women than for men is not supported by this study.

(Occup Environ Med 2001;58:52-57)

Dr B Floderus

Birgitta.floderus@imm.ki.se

Accepted 30 August 2000 Keywords: mortality; unemployment; overtime work
Results-Unemployment in 1973 among

It is well known that unemployment is associated with health variables - such as increased consumption of health care, mortality, and psychological ill health. ${ }^{1-6}$ Overtime work has been suggested to contribute to increased levels of stress hormones ${ }^{7}$ and to increased mortality from cardiovascular diseases. $^{89}$

Most studies on unemployment are based on men but a few concern women, ${ }^{10} 11$ or are comparisons between the two sexes. Part time work, overtime work, and extra work, are conditions that have only been studied sparsely from the perspective of sex. ${ }^{12}$ No studies on unemployment and mortality have included control for potential confounding factors such as family structure, lifestyle habits, and personality factors, within the same study.

In Sweden $79 \%$ of the men and $75 \%$ of the women between 16-65 years of age were employed or applied for a job ${ }^{13}$ in 1997, compared with $80 \%$ men and $57 \%$ women in $1974 .^{14}$

The Swedish labour market was relatively stable between 1950 and 1990, with unemployment rates of about $2 \%$, never exceeding $4 \% .^{15}$ Today, structural changes, changes in working time, and changes in working contracts, have divided the labour market into three parts: good, secure, and well paid jobs, an increasing proportion of temporary jobs, and unemployment. ${ }^{12}$ In Sweden, as in other European countries, unemployment has increased during the 1990 s, in Sweden from about $1.5 \%$ to $8 \%$. Including people partially unemployed, the figures were $20 \%$ for women and $16 \%$ for men in 1995. ${ }^{12}$ During the same period, the amount of overtime work increased for those who had employment. ${ }^{13}$

Although most women have joined the labour force during the past 30-40 years, many continue to take a greater responsibility for their children and household than do most men. ${ }^{16}$ The proportion of women and men working part time was $38 \%$ and $9 \%$, respectively in $1997 . .^{13}$ Many women have part time employment to balance the demands from household duties whereas most men have part time work due to health problems. ${ }^{12}{ }^{17} \mathrm{~A}$ combination of professional and household work is often to be preferred from a health perspective as long as the total workload does not get excessive, a situation which may induce negative health consequences. ${ }^{18}$

The aim of the present study was to examine 
Table 1 Description of the study population and exposure variables

\begin{tabular}{|c|c|c|c|c|}
\hline & \multicolumn{2}{|l|}{ Women } & \multicolumn{2}{|l|}{ Men } \\
\hline & $n$ & $\%$ & $n$ & $\%$ \\
\hline People included in the data collection & 18516 & & 18020 & \\
\hline Respondents & 15874 & 85.7 & 14458 & 80.2 \\
\hline The cohort ${ }^{\star}$ & 15683 & & 14287 & \\
\hline Deaths 1973-96 & 862 & 5.5 & 1331 & 9.3 \\
\hline Participants without job titles & 6183 & 39.4 & 3155 & 22.1 \\
\hline Participants with job titles & 9500 & 100.0 & 11132 & 100.0 \\
\hline Deaths 1973-96 & 424 & 4.5 & 836 & 7.5 \\
\hline \multicolumn{5}{|l|}{ Exposure variables: } \\
\hline \multicolumn{5}{|l|}{ Unemployment: } \\
\hline Ever unemployed & 875 & 9.2 & 1309 & 11.8 \\
\hline Unemployed in 1973 & 263 & 2.8 & 315 & 2.8 \\
\hline Unemployed earlier but work in 1973 & 612 & 6.4 & 994 & 8.9 \\
\hline Part time work & 2993 & 31.5 & 237 & 2.1 \\
\hline \multicolumn{5}{|l|}{ Overtime work: } \\
\hline$\leqslant 5 \mathrm{~h} /$ week & 497 & 5.2 & 1457 & 13.1 \\
\hline$>5 \mathrm{~h} /$ week & 249 & 2.6 & 1505 & 13.5 \\
\hline \multicolumn{5}{|l|}{ Extra work: } \\
\hline$\leqslant 5 \mathrm{~h} /$ week & 350 & 3.7 & 844 & 7.6 \\
\hline$>5 \mathrm{~h} /$ week & 362 & 3.8 & 1013 & 9.1 \\
\hline
\end{tabular}

*191 Women and 171 men could not be identified when matching with the Causes of Death Registry.

and men relative to unemployment, part time work, overtime work, and extra work, including an emphasis on the importance of confounding from different social, behavioural, work, and health related factors.

The study cohort is part of the Swedish twin registry, but the subjects were treated as a sample from the general population irrespective of the twinning. ${ }^{19}$ It has been shown that twins do not deviate from non-twins for social and behavioural factors such as number of siblings, number of children, education, marital status, place of residence, smoking behaviour, and symptoms of lung or heart problems. ${ }^{19}$ Also, for mortality and common causes of death (after the prenatal and neonatal period $)^{20}$ as well as cancer morbidity, ${ }^{21}$ twins are highly comparable with the general population.

\section{Material and methods}

STUDY GROUP

The study cohort comprised in principle all like sexed twins born in Sweden in 1926-58. ${ }^{22}$ Data are based on a postal questionnaire of 1973, which was answered by 15683 women and 14287 men (table 1) and on information from the Causes of Death Registry. All subjects with a defined job title were selected, 9500 women and 11132 men. A defined job title means that the subject had specified a main occupation in the questionnaire. Housewives, students, pensioners, people on disablement pension, and people liable for military service were not included. Mortality from all causes during 1973-96 was analyzed.

\section{EXPOSURE FACTORS}

The postal questionnaire comprised questions about medical symptoms, use of medication, smoking and drinking habits, personality factors, psychosocial status, and demographic data. A short occupational history was also recorded including the occupational factors that were the focus in this study. The different exposure variables, how they were dichotomised, and their prevalence in the study group are shown in table 1 . The three exposure variables of unemployment were constructed from the questions "Are you now or have you earlier been unemployed?", "Are you employed at the present time?". The dichotomisation for overtime work was based on the question "How many hours a week do you work overtime?". For extra work (other than permanent work) the questions were "Have you now or have you earlier had an extra job? How many hours a week?".

\section{MORTALITY}

The twin registry is matched on a regular basis with central population registries such as the Causes of Death Registry. In this study, mortality has been analyzed regardless of specific causes of death. The 24 year follow up was considered as a continuous period, and also was divided into different time windows, the first 5 years including 1973, the subsequent 10 year period, and the remaining 9 years of observation.

\section{POTENTIAL CONFOUNDING FACTORS}

The following potential confounding or mediating factors were taken into account: age, marital status, children, education, smoking and alcohol habits, use of sleeping pills and tranquilisers, stress, shift work, personality factors, and long lasting or serious illness. The variables were dichotomised as follows: the exposed variable precedes the unexposed; unmarried, divorced, and widowed versus married and cohabiting; no children versus one or more children; elementary school versus more than elementary school; former smoker and smoker versus non-smoker; no alcoholic beverages versus 1-250 g alcohol/month; $>250 \mathrm{~g}$ alcohol/month versus $1-250 \mathrm{~g}$ alcohol/ month; sleeping pills taken regularly or occasionally versus hardly ever; tranquilisers taken regularly or occasionally versus hardly ever; stressful life versus no stress; shift work versus no shift work; unstable personality $>4$ points versus stable personality $<5$ points; extravert personality $>4$ points versus intravert personality $<5$ points; ever long lasting or serious illness versus never long lasting or serious illness.

Alcohol consumption was analyzed by $\mathrm{g}$ absolute alcohol. ${ }^{22}$ Stressful life was defined by the question "Do you consider your everyday life to be very stressful?" The personality factors instability and introversion or extraversion were based on nine items each, selected from the neuroticism and extraversion dimensions of the Eysenck personality inventory. These short scales were developed to fit into comprehensive questionnaire investigations. ${ }^{23}$ The potential confounder of ill health was described by the question "Have you ever had any long term or serious illness?".

\section{STATISTICAL ANALYSIS}

Relative risks (RRs) and 95\% confidence intervals (95\% CIs) were computed by Cox's proportional hazards model ${ }^{24}$ according to the PHREG of the statistical analysis system (SAS 6.12) with calendar years as the underlying dimension. Age at start of follow up was included on a 1 year basis. 
Table 2 Mortality relative to unemployment and different time aspects of work for the first 5 years and the total follow up period (rate ratio (RR) (95\% Cl) for women

\begin{tabular}{|c|c|c|c|c|c|c|c|c|}
\hline \multirow[b]{3}{*}{ Variables } & \multicolumn{4}{|c|}{24 Year follow $u p^{\star}$} & \multicolumn{4}{|l|}{5 Year follow $u p^{\star}$} \\
\hline & \multicolumn{2}{|l|}{ Age adjusted } & \multicolumn{2}{|l|}{ Full model $\neq$} & \multicolumn{2}{|l|}{ Age adjusted } & \multicolumn{2}{|l|}{ Full model $\neq$} \\
\hline & $R R(95 \% C I)$ & $n t$ & $R R(95 \% C I)$ & $n t$ & $R R(95 \% C I)$ & $n t$ & $R R(95 \% C I)$ & $n+$ \\
\hline Ever unemployed & $\begin{array}{l}1.72 \\
(1.26 \text { to } 2.36)\end{array}$ & $\begin{array}{l}411 \\
(45)\end{array}$ & $\begin{array}{l}1.62 \\
(1.11 \text { to } 2.35)\end{array}$ & $\begin{array}{l}279 \\
(33)\end{array}$ & $\begin{array}{l}2.07 \\
(0.71 \text { to } 6.08)\end{array}$ & $\begin{array}{l}29 \\
(4)\end{array}$ & $\begin{array}{l}2.23 \\
(0.62 \text { to } 7.97)\end{array}$ & $\begin{array}{l}20 \\
\text { (3) }\end{array}$ \\
\hline Unemployed 1973 & $\begin{array}{l}2.25 \\
(1.43 \text { to } 3.53)\end{array}$ & $\begin{array}{l}386 \\
(20)\end{array}$ & $\begin{array}{l}1.98 \\
(1.16 \text { to } 3.38)\end{array}$ & $\begin{array}{l}261 \\
(15)\end{array}$ & $\begin{array}{l}1.54 \\
(0.21 \text { to } 11.43)\end{array}$ & $\begin{array}{l}26 \\
(1)\end{array}$ & $\begin{array}{l}2.60 \\
(0.33 \text { to } 20.55)\end{array}$ & $\begin{array}{l}18 \\
(1)\end{array}$ \\
\hline $\begin{array}{l}\text { Unemployed earlier, work } \\
1973\end{array}$ & $\begin{array}{l}1.45 \\
(0.96 \text { to } 2.18)\end{array}$ & $\begin{array}{l}391 \\
(25)\end{array}$ & $\begin{array}{l}1.42 \\
(0.87 \text { to } 2.32)\end{array}$ & $\begin{array}{l}264 \\
(18)\end{array}$ & $\begin{array}{l}2.29 \\
(0.67 \text { to } 7.79)\end{array}$ & $\begin{array}{l}28 \\
(3)\end{array}$ & $\begin{array}{l}2.09 \\
(0.46 \text { to } 9.45)\end{array}$ & $\begin{array}{l}19 \\
(2)\end{array}$ \\
\hline Part time work & $\begin{array}{l}0.81 \\
(0.65 \text { to } 1.01)\end{array}$ & $\begin{array}{l}354 \\
(142)\end{array}$ & $\begin{array}{l}0.95 \\
(0.72 \text { to } 1.26)\end{array}$ & $\begin{array}{l}244 \\
(100)\end{array}$ & $\begin{array}{l}0.47 \\
(0.20 \text { to } 1.15)\end{array}$ & $\begin{array}{l}26 \\
(7)\end{array}$ & $\begin{array}{l}0.40 \\
(0.12 \text { to } 1.33)\end{array}$ & $\begin{array}{l}17 \\
(4)\end{array}$ \\
\hline Overtime work $\leqslant 5 \mathrm{~h} /$ week & $\begin{array}{l}0.85 \\
(0.52 \text { to } 1.38)\end{array}$ & $\begin{array}{l}348 \\
(17)\end{array}$ & $\begin{array}{l}0.78 \\
(0.44 \text { to } 1.40)\end{array}$ & $\begin{array}{l}240 \\
(12)\end{array}$ & - & $\begin{array}{l}26 \\
(0)\end{array}$ & - & $\begin{array}{l}17 \\
(0)\end{array}$ \\
\hline Overtime work $>5 \mathrm{~h} /$ week & $\begin{array}{l}1.69 \\
(1.06 \text { to } 2.69)\end{array}$ & $\begin{array}{l}348 \\
(19)\end{array}$ & $\begin{array}{l}1.92 \\
(1.13 \text { to } 3.25)\end{array}$ & $\begin{array}{l}240 \\
(15)\end{array}$ & - & $\begin{array}{l}26 \\
(0)\end{array}$ & - & $\begin{array}{l}17 \\
(0)\end{array}$ \\
\hline Extra work $\leqslant 5 \mathrm{~h} /$ week & $\begin{array}{l}1.18 \\
(0.71 \text { to } 1.95)\end{array}$ & $\begin{array}{l}350 \\
(16)\end{array}$ & $\begin{array}{l}1.05 \\
(0.59 \text { to } 1.89)\end{array}$ & $\begin{array}{l}240 \\
(12)\end{array}$ & $\begin{array}{l}0.89 \\
(0.12 \text { to } 6.58)\end{array}$ & $\begin{array}{l}26 \\
(1)\end{array}$ & $\begin{array}{l}1.19 \\
(0.16 \text { to } 9.08)\end{array}$ & $\begin{array}{l}17 \\
(1)\end{array}$ \\
\hline Extra work $>5 \mathrm{~h} /$ week & $\begin{array}{l}1.70 \\
(1.09 \text { to } 2.65)\end{array}$ & $\begin{array}{l}350 \\
(21)\end{array}$ & $\begin{array}{l}1.30 \\
(0.74 \text { to } 2.29)\end{array}$ & $\begin{array}{l}240 \\
(13)\end{array}$ & - & $\begin{array}{l}26 \\
(0)\end{array}$ & - & $\begin{array}{l}17 \\
(0)\end{array}$ \\
\hline
\end{tabular}

* Age adjusted model is based on 7899-9248 subjects; the full model is based on 5425-6329 subjects depending on the number of missing values.

†Number of cases (number of exposed cases).

†Adjusted for age, marital status, smoking, alcohol consumption, use of tranquilisers, extraversion, and long lasting or serious illness

- No exposed cases.

Firstly, the exposure factors were studied with adjustment for age only. Secondly, all potential confounding factors were analyzed together relative to mortality, and the factors yielding an $R R>1.30$, or a lower confidence limit $>1.00$ for either the entire study period or for the first 5 year period were retained in a final regression model for each exposure factor. Also, factors with a point estimate below unity and an upper confidence interval $<1.00$ were retained.

The factors showing an independent association with mortality according to the criteria described were, for women: age, marital status, smoking and alcohol habits, use of tranquilisers, extraversion as a personality factor, and long lasting or serious illness. For men, the corresponding factors were: age, marital status, smoking and alcohol habits, use of sleeping pills, instability as a personality factor, and long lasting or serious illness.

The subjects were treated as a sample from the general population regardless of the twinning. ${ }^{19}$ For one of the main results, the full model was also analysed on subgroups where the twins in a pair were randomly distributed on two independent samples. This procedure was repeated six times, with the objective of assessing the difference between using only one in a pair or using both as independent people.

\section{Results}

Mortalities relative to unemployment and other time aspects of work are presented separately for women and men (tables 2 and 3), to condense the sex specific outcome. On the other hand, the later results are presented by type of exposure factor.

\section{UNEMPLOYMENT}

For the 24 year follow up, a more than doubled mortality was found for women who were unemployed in 1973 and a $40 \%$ increase in risk was found for those who reported that they had been unemployed earlier but worked in 1973 . Ever unemployed yielded a $70 \%$ increase in

Table 3 Mortality relative to unemployment and different time aspects of work for the first 5 years and the total follow up period (rate ratio (RR) (95\% Cl) for men)

\begin{tabular}{|c|c|c|c|c|c|c|c|c|}
\hline \multirow[b]{3}{*}{ Variables } & \multicolumn{4}{|c|}{24 Year follow $u p^{*}$} & \multicolumn{4}{|l|}{5 Year follow up ${ }^{\star}$} \\
\hline & \multicolumn{2}{|l|}{ Age adjusted } & \multicolumn{2}{|l|}{ Full model $\neq$} & \multicolumn{2}{|l|}{ Age adjusted } & \multicolumn{2}{|l|}{ Full model $\neq$} \\
\hline & $R R(95 \% C I)$ & $n t$ & $R R(95 \% C I)$ & $n t$ & $R R(95 \% C I)$ & $n+$ & $R R(95 \% C I)$ & $n t$ \\
\hline Ever unemployed & $\begin{array}{l}1.55 \\
(1.25 \text { to } 1.91)\end{array}$ & $\begin{array}{l}817 \\
(102)\end{array}$ & $\begin{array}{l}1.34 \\
(1.03 \text { to } 1.73)\end{array}$ & $\begin{array}{l}547 \\
(70)\end{array}$ & $\begin{array}{l}2.21 \\
(1.27 \text { to } 3.85)\end{array}$ & $\begin{array}{l}84 \\
(16)\end{array}$ & $\begin{array}{l}1.52 \\
(0.75 \text { to } 3.09)\end{array}$ & $\begin{array}{l}58 \\
(10)\end{array}$ \\
\hline Unemployed in 1973 & $\begin{array}{l}1.96 \\
(1.39 \text { to } 2.76)\end{array}$ & $\begin{array}{l}749 \\
(34)\end{array}$ & $\begin{array}{l}1.43 \\
(0.91 \text { to } 2.25)\end{array}$ & $\begin{array}{l}498 \\
(21)\end{array}$ & $\begin{array}{l}4.83 \\
(2.40 \text { to } 9.70)\end{array}$ & $\begin{array}{l}77 \\
(9)\end{array}$ & $\begin{array}{l}3.29 \\
(1.33 \text { to } 8.17)\end{array}$ & $\begin{array}{l}54 \\
(6)\end{array}$ \\
\hline $\begin{array}{l}\text { Unemployed earlier, work in } \\
1973\end{array}$ & $\begin{array}{l}1.39 \\
(1.08 \text { to } 1.78)\end{array}$ & $\begin{array}{l}783 \\
(68)\end{array}$ & $\begin{array}{l}1.29 \\
(0.95 \text { to } 1.74)\end{array}$ & $\begin{array}{l}526 \\
(49)\end{array}$ & $\begin{array}{l}1.26 \\
(0.57 \text { to } 2.78)\end{array}$ & $\begin{array}{l}75 \\
(7)\end{array}$ & $\begin{array}{l}0.86 \\
(0.31 \text { to } 2.43)\end{array}$ & $\begin{array}{l}52 \\
(4)\end{array}$ \\
\hline Part time work & $\begin{array}{l}1.49 \\
(0.92 \text { to } 2.41)\end{array}$ & $\begin{array}{l}698 \\
(17)\end{array}$ & $\begin{array}{l}1.58 \\
(0.91 \text { to } 2.77)\end{array}$ & $\begin{array}{l}477 \\
(13)\end{array}$ & $\begin{array}{l}2.76 \\
(0.86 \text { to } 8.92)\end{array}$ & $\begin{array}{l}58 \\
(3)\end{array}$ & $\begin{array}{l}3.15 \\
(0.94 \text { to } 10.59)\end{array}$ & $\begin{array}{l}41 \\
(3)\end{array}$ \\
\hline Overtime work $\leqslant 5 \mathrm{~h} /$ week & $\begin{array}{l}0.63 \\
(0.49 \text { to } 0.81)\end{array}$ & $\begin{array}{l}692 \\
(72)\end{array}$ & $\begin{array}{l}0.58 \\
(0.43 \text { to } 0.80)\end{array}$ & $\begin{array}{l}472 \\
(45)\end{array}$ & $\begin{array}{l}0.84 \\
(0.37 \text { to } 1.88)\end{array}$ & $\begin{array}{l}61 \\
(7)\end{array}$ & $\begin{array}{l}0.71 \\
(0.25 \text { to } 2.06)\end{array}$ & $\begin{array}{l}42 \\
(4)\end{array}$ \\
\hline Overtime work $>5 \mathrm{~h} /$ week & $\begin{array}{l}1.08 \\
(0.89 \text { to } 1.31)\end{array}$ & $\begin{array}{l}692 \\
(135)\end{array}$ & $\begin{array}{l}1.15 \\
(0.92 \text { to } 1.44)\end{array}$ & $\begin{array}{l}472 \\
(103)\end{array}$ & $\begin{array}{l}1.87 \\
(1.05 \text { to } 3.34)\end{array}$ & $\begin{array}{l}61 \\
(17)\end{array}$ & $\begin{array}{l}2.00 \\
(1.02 \text { to } 3.95)\end{array}$ & $\begin{array}{l}42 \\
(13)\end{array}$ \\
\hline Extra work $\leqslant 5 \mathrm{~h} /$ week & $\begin{array}{l}0.87 \\
(0.66 \text { to } 1.16)\end{array}$ & $\begin{array}{l}683 \\
(52)\end{array}$ & $\begin{array}{l}0.91 \\
(0.65 \text { to } 1.27)\end{array}$ & $\begin{array}{l}472 \\
(39)\end{array}$ & $\begin{array}{l}1.38 \\
(0.58 \text { to } 3.24)\end{array}$ & $\begin{array}{l}58 \\
(6)\end{array}$ & $\begin{array}{l}1.94 \\
(0.79 \text { to } 4.72)\end{array}$ & $\begin{array}{l}41 \\
(6)\end{array}$ \\
\hline Extra work $>5 \mathrm{~h} /$ week & $\begin{array}{l}1.37 \\
(1.10 \text { to } 1.71)\end{array}$ & $\begin{array}{l}683 \\
(93)\end{array}$ & $\begin{array}{l}1.29 \\
(0.99 \text { to } 1.69)\end{array}$ & $\begin{array}{l}472 \\
(65)\end{array}$ & $\begin{array}{l}2.33 \\
(1.22 \text { to } 4.44)\end{array}$ & $\begin{array}{l}58 \\
(12)\end{array}$ & $\begin{array}{l}2.57 \\
(1.20 \text { to } 5.52)\end{array}$ & $\begin{array}{l}41 \\
(9)\end{array}$ \\
\hline
\end{tabular}

*Age adjusted model is based on 9681-10975 subjects; the full model is based on 6716-7512 subjects depending on the number of missing values. †Number of cases (number of exposed cases).

‡Adjusted for age, marital status, smoking, alcohol consumption, use of sleeping pills, instability, and long lasting or serious illness. 


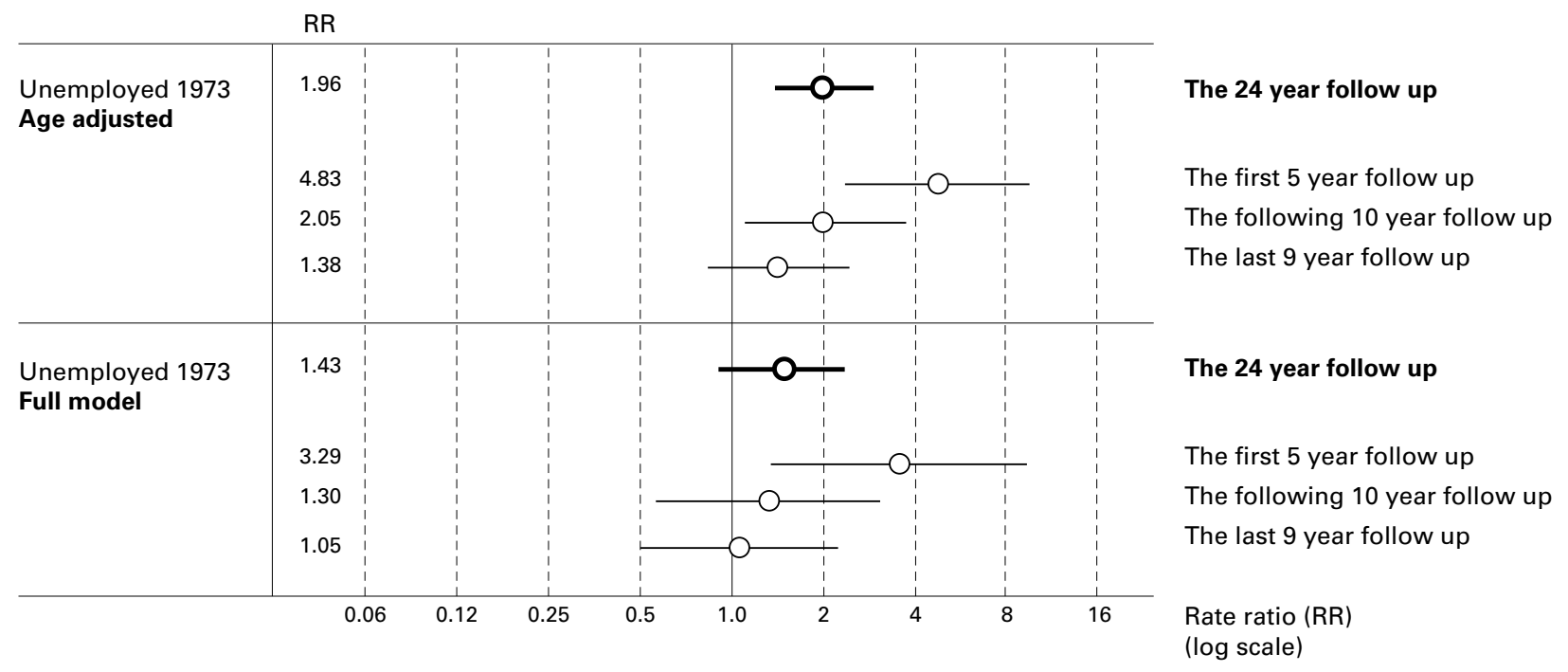

Figure 1 Mortality RR (95\% CI), among men, unemployed in 1973, by time of follow up.

Table 4 Assesment of the confounding effect from each of the factors considered in the final model (unemployment in 1973 relative to mortality)

\begin{tabular}{|c|c|c|}
\hline & Women RR $(95 \%$ CI $) \dagger$ & Men RR $(95 \% C I) \dagger$ \\
\hline Full model & $1.98(1.16$ to 3.38$)$ & $1.43(0.91$ to 2.25$)$ \\
\hline \multicolumn{3}{|c|}{ Factor excluded from the full model: ${ }^{\star}$} \\
\hline Marital status & $1.98(1.16$ to 3.37$)$ & $1.57(1.00$ to 2.45$)$ \\
\hline Smoking habits & $2.09(1.23$ to 3.56$)$ & $1.52(0.97$ to 2.38$)$ \\
\hline Alcohol consumption & $1.88(1.17$ to 3.00$)$ & $1.49(1.01$ to 2.18$)$ \\
\hline Tranquilisers & $2.05(1.22$ to 3.43$)$ & \\
\hline Sleeping pills & & $1.53(1.01$ to 2.33$)$ \\
\hline Extraversion & $2.00(1.17$ to 3.40$)$ & \\
\hline Instability & & 1.51 (0.97 to 2.37$)$ \\
\hline Long lasting illness & $2.03(1.19$ to 3.46$)$ & $1.47(0.94$ to 2.29$)$ \\
\hline
\end{tabular}

${ }^{\star}$ New models with one confounding factor excluded, one at a time, from the full model. $+R R=$ rate ratio.

risk. After adjustment for confounding, unemployment in 1973 still showed a clear association with mortality, and the results for unemployment earlier or ever were largely unaffected. Results for the first 5 years of follow up, were hampered for women, by the low mortality. Also for men an increased mortality was found for the 24 year period, and the outcome was further strengthened by the analyses of the first 5 year follow up where there was an almost fivefold increase in risk for being unemployed in 1973. The associations decreased when controlling for confounding. The strength of the association between unemployment in 1973 and mortality for men, relative to the different time windows, is illustrated in the figure.

The confounding effect from the different factors was further studied for unemployment in 1973 (table 4). For women smoking habit was most important; and for men, marital status was the factor with the largest impact on the relation. The specific effect of ill health was further studied by excluding subjects reporting long lasting or serious illness. For women an even stronger association was found for unemployment in 1973, with an RR (95\% CI) of 2.60 (1.40 to 4.83 ), whereas the results for men were unaffected, 1.48 (0.83 to 2.65 ).

PART TIME WORK

For women, part time work seemed to reduce the mortality when only age was controlled for.
This protective effect disappeared when also adjusting for confounding from other factors. An opposite situation was found for men where part time work increased the mortality. After adjusting for possible confounding factors the risk estimate was still increased, and the association was strengthened by the outcome for the first 5 year follow up, although based on smaller numbers.

OVERTIME WORK

A protective effect from overtime work up to a maximum 5 hours a week was found for men. This finding also remained after adjustment for confounding. The same tendency was found for women.

For overtime work of more than 5 hours a week an association with mortality was found for women, which remained after consideration of potential confounding factors. For men such a relation was found only for the first 5 years of follow up.

\section{EXTRA WORK}

The mortality for men with extra work up to a maximum 5 hours a week was increased only for the first 5 years of follow up. For women no association was found.

Extra work of more than 5 hours a week for men was associated with an increased mortality, which was more evident for the first 5 years of follow up. For women, an association was also found, but there were indications that the outcome was influenced by confounding from the factors considered in the full model.

\section{Discussion}

In the present study the opportunity offered by the Swedish twin registry ${ }^{22}$ was used to study long term mortality among women and men relative to unemployment, part time work, overtime work, and extra work. A major advantage of the study was the ability to take into consideration the potential impact of many social, behavioural, work, and health related factors on these relations.

Unemployment showed the strongest association with subsequent mortality, and the risk 
estimates were consistent with previous studies. ${ }^{46}{ }^{11} \mathrm{~A}$ comparable relation between unemployment in 1973 and the subsequent 24 year mortality was found for men and women. It has been suggested that the work role is less important for women than for men and that losing a job has less importance for women. ${ }^{5}$ The present results do not support this view, which may be due to different definitions of work and unemployment. If anything, the increased mortality after unemployment was more evident among women in our study.

In discussions of the association between unemployment and health, confounding has often been brought out as a problem in the interpretation. ${ }^{4125}$ Here, not only social factors-such as marital status and childrenbut also education, smoking and alcohol habits, use of sleeping pills and tranquilisers, stress, shift work, personality factors, and long lasting or serious illness, have been taken into account. The evaluation of the confounding effect from each of the factors considered (table 4), showed a comparatively weak effect for all factors. For women, smoking showed the largest effects; whereas for men, marital status had the largest impact on the risk estimate. It should be pointed out, however, that some of these factors might, to some extent, have been a consequence of unemployment; and if so, the unadjusted $R R$ should be a more valid measure of the relation between unemployment and mortality. The personality factors (instability and introversion or extraversion) were derived from personality dimensions of the Eysenck personality inventory, dimensions claimed to be relatively stable characteristics of the person. ${ }^{26}$

After adjustment for long lasting or serious illness, the results may still be influenced by selective illness. The question used may have a low sensitivity and probably fails to capture all types of illness. This could imply an overestimation of the effect due to unemployment.

Martikainen and Valkonen ${ }^{11}$ showed that the relation between unemployment and mortality was stronger in times with low unemployment and that the association decreased with increasing rates of unemployment. This could be explained by health related selection, with an overrepresentation of illness preceding or following unemployment, ${ }^{23}$ or that harmful effects-for example, psychosocial stress or stigmatisation - may be more pronounced in times with few unemployed people. ${ }^{11}$ The present study refers to a period with a low and relatively constant unemployment rate.

Economic problems may lead to restrictions of lifestyle with little opportunity for recreation and recovery. Extra work may be a marker of economic stress which may contribute to illness, ${ }^{27}$ and could explain the somewhat increased mortality in this study among both women and men who reported extra work of more than 5 hours a week.

Not only for extra work, but also for overtime work of more than 5 hours a week, there was an association with increased mortality among women. The outcome may be explained by the fact that women take much of the responsibil- ity and unpaid work at home, and if combined with more than full time work, the total workload may pass a threshold with adverse health effects. Men had a reduced mortality relative to moderate overtime work, 5 hours a week or less, which may reflect a devotion to work or a stimulating work environment entailing positive health effects. However, this could also be a reflection of a healthy worker selection.

The results showed a discrepancy between men and women for part time work. As expected, ${ }^{12}$ part time work was a risk indicator for men, possibly because it is a marker of impaired health, an impairment that was not controlled for by the answers to the question on long lasting or serious illness. Among women, part time work was not linked with an increased mortality. On the contrary, there was to a certain extent a reduced mortality, which might signify that full time work, 40 hours a week, is not the optimal work time for most women, given the traditional workload at home. ${ }^{18}$

The assessment of the different exposure variables refers to one point in time, 1973. The changes in exposure for the study subjects over the decades were not possible to measure. A fraction of those classified as unexposed has been exposed during the follow up, and among those classified as exposed there should be a wide range of duration of exposure. We think that the validity of the exposure classification is highest for the time closest to the data collection. Among women, the number of cases during the first 5 year period was very small. Among men, the precision was also decreased for that time window, but several of the point estimates were more pronounced for the first 5 year period. This suggests that the results for the 24 year period may be diluted by misclassification of the exposures (apart from a time dependent reduction of the RR).

The identification of dead subjects should have a very high sensitivity and specificity, so there should not be any bias in the mortality data. However, higher death rates were found among those who did not answer the questionnaire, and it may be that the non-respondents (17\%) comprise an excess number of exposed (unemployed) subjects. The effects of the drop out are not possible to assess. We think that a potential selection bias has reduced rather than produced the associations found-for example, the increased mortality in unemployed subjects.

An improved precision when using both twins in a pair instead of only one was found in the sensitivity study where the twins were randomly distributed on two independent samples. The differences between the point estimates of the RRs from the six repeated analyses showed for men who were unemployed in 1973, a range of RR (95\% CI) from 1.06 (0.49 to 2.27 ) to 1.76 (0.92 to 3.38 ) and a mean RR corresponding to the result based on the whole cohort, of 1.43. A consistent association between unemployment and mortality was also suggested by the results from conditional logistic regression analysis of death discordant twin pairs. 
The cohort comprises subjects who had specified a main occupation, which means that the associations are not influenced by mortality among groups outside the workforce. The prevalence of unemployed subjects in the cohort corresponds with population statistics of that time, ${ }^{14}$ and the same applies to the occurrence of overtime work. This strengthens the assumption that the study subjects are representative of the general population. The proportion of women reporting overtime work in 1973 (8\%) differs markedly from figures of today $(23 \%)$, mainly due to the expanded and intensified work patterns among women.

In this study, no attention was paid to specific causes of death. This issue should be interesting to pursue particularly relative to unemployment, as such knowledge could be of importance in preventive work. Another area that should be further explored is the partitioning of time between work and private life, including a sex perspective, with the aim to improve health and wellbeing among men and women.

\section{Conclusions}

Unemployment, but also lengthy working hours, were associated with increased mortality for both women and men. This association remained when social, behavioural, work, and health related factors were taken into consideration. Despite the fact that the data reflect the situation in 1973 these results are especially relevant today, because of the situation on the labour market. Unemployment may vary greatly over decades, and across different occupational groups. At the same time a considerable proportion of women and men perform much overtime work as well as unpaid work at home. From a public health perspective it seems important to share and balance the total workload.

The Swedish twin registry is supported by grants from the Swedish Council for the Planning and Coordination of Research (FRN), the Swedish Social Research Council, and the MacArthur Foundation Research Network on Successful Ageing.

1 Costa G, Segnan N. Unemployment and mortality. BMF 1987;294:1550-1.

2 Iversen L, Andersen O, Andersen P, et al. Unemployment and mortality in Denmark, 1970-80. BMF 1987;295:87984.

3 Martikainen PT. Unemployment and mortality among Finnish men, 1981-5. BMF 1990;301:407-11.

4 Moser KA, Fox AJ, Jones DR. Unemployment and mortality in the OPCS longitudinal study. Lancet 1984;ii: 1324-9.
5 Stefansson CG. Long-term unemployment and mortality in Sweden, 1980-6. Soc Sci Med 1991;32:419-23.

6 Wilson SH, Walker GM. Unemployment and health: a review. Public Health 1993;107:153-62.

7 Åkerstedt T. Arbetstider, hälsa och säkerhet (Work hours, health and safety; in Swedish). Stockholm, Sweden: National Institute for Psychosocial Factors and Health, 1996. (Stress Research Report No 270.)

8 Starrin B, Larsson G, Brenner SO, et al. Structural changes, ill health, and mortality in Sweden, 1963-83: a macroaggregated study. Int $\mathcal{F}$ Health Serv 1990;20:27-42.

9 Alfredsson L, Spetz CL, Theorell T. Type of occupation and near-future hospitalization for myocardial infarction and some other diagnoses. Int $\mathcal{F}$ Epidemiol 1985;14:378-88.

10 Brenner SO, Levi L. Long-term unemployment among women in Sweden. Soc Sci Med 1987;25:153-61.

11 Martikainen PT, Valkonen T. Excess mortality of unemployed men and women during a period of rapidly increasing unemployment. Lancet 1996;348:909-12.

12 Gonäs L, Spånt A. Trends and prospects for women's employment in the 1990s. Arbete och Hälsa 1997:4. Solna, Sweden: National Institute for Working Life, 1997.

13 Statistics Sweden. Statistical yearbook of Sweden 99. Stockholm, Sweden: Statistics Sweden, 1999.

14 Statistics Sweden. Statistical yearbook of Sweden 75. Stockholm, Sweden: Statistics Sweden, 1975.

15 Nordenmark M. Unemployment, employment commitment and wellbeing. The psychosocial meaning of (un)employment among women and men. Umeå, Sweden: Department of SociologyUmeå University, 1999. (No 101999.$)$

16 Tyrkkö A. Anpassning mellan arbetsliv och familjeliv i Sverige och Finland (Adaptation to work life and family life in Sweden and Finland; in Swedish). In: Bonke J, ed. Dilemmaet arbejdsliv-familieliv $i$ Norden. Socialforskningsinstituttet 97:5, Nordiska Ministerrådet TemaNord 1997:534. Copenhagen, Denmark: Socialforskningsinstituttet, Nordiska Ministerrådet, 1997:109-156.

17 Vogel J. Konflikter mellan privatlivet och arbetet (Conflicts between privat life and work; in Swedish). In: Vogel J, Kindlund H, Diderichsen F, eds. Arbetsförhållanden, ohälsa och sjukfränvaro 1975-89. Levnadsförhållanden. Stockholm, Sweden: Statistics Sweden, 1992:111-133. (Rapport 78.)

18 Lundberg U, Mårdberg B, Frankenhaeuser $M$. The total workload of male and female white collar workers as related to age, occupational level, and number of children. Scand $\mathcal{f}$ Psychol 1994;35:315-27.

19 Cederlöf R. The twin method in epidemiological studies on chronic disease. Stockholm, Sweden: University of Stockholm, 1966

20 Cederlöf R, Floderus-Myrhed B. Cancer mortality and morbidity among 23,000 unselected twin pairs. In: Gelboin HV, Macmahon B, Matsumishima T, et al, eds. Genetic and environmental factors in experimental and human cancer. Tokyo: Japan Sci Soc Press, 1980:151-60.

21 Braun MM, Ahlbom A, Floderus B, et al. Effect of twinship on incidence of cancer of the testis, breast, and other sites (Sweden). Cancer Causes Control 1995;6:519-24.

22 Medlund P, Cederlöf R, Floderus B, et al. A new Swedish twin registry. Acta Medica Scandinavia 1976(suppl 600).

23 Floderus B. Psycho-social factors in relation to coronary heart disease and associated risk factors. Nordisk Hygienisk Tidskrift 1974(suppl 6).

24 Clayton D, Hills M. Statistical models in epidemiology. New York: Oxford University Press, 1993.

25 Janlert U. Unemployment as a disease, and diseases of the unemployed. Scand $\mathcal{F}$ Work Environ Health 1997;23(suppl 3):79-83.

26 Floderus-Myrhed B, Pedersen N, Rasmuson I. Assessment of heritability for personality, based on a short-form of the Eysenck personality inventory: a study of 12898 twin pairs. Behav Genet 1980;10:153-62.

27 Starrin B, Jönsson LR. Ekonomisk påfrestning, skamgörande erfarenheter och ohälsa under arbetslöshet. En prövning av ekonomi-skam modellen (Economical strain, experiences of shame and ill health during unemployment; in Swedish). Arbetsmarknad and Arbetsliv 1998;4:91-108. 